\title{
INTERNATIONAL JOURNAL Of RESEARCH

\section{RESEARCH ON FEATURED INDUSTRY OF TALENT CULTIVATION OF HIGHER VOCATIONAL AND TECHNOLOGICAL EDUCATION IN} TAIWAN

Hsu, How-Gao ${ }^{1}$, Lin, Ching-Nan* ${ }^{2}$

${ }^{1}$ Department of Industrial Education, National Taiwan Normal University, Taipei, Taiwan

$2^{*}$ Department of Industrial Education, National Taiwan Normal University, Taipei, Taiwan *Correspondence Author: jfvs101@mail.jfvs.tpc.edu.tw

\begin{abstract}
:
This research intends to explore the planning of featured industry of talent cultivation for national universities and colleges of technology in Taiwan. This research is conducted through current status analyses from each itemized subsidy plan of Ministry of Education towards national universities and colleges of technology; in addition, the industrial analyses broken down by fields as well as the definitions for each field by professional counseling surveys are also applied in the process. Moreover, from the main themes and focal points for each school's development and the recommendations for industrial human resource cultivation, this research manages to study each processing item of the plan for each field and corresponding funding allocations. Thus, this research derives the development direction and resource requirements of foresight talent cultivation for national universities and colleges of technology in Taiwan. And ensuing promotion and implementation can then be planned accordingly.
\end{abstract}

Keywords:

Higher vocational and technological education, Featured industry, Talent cultivation.

\section{FOREWORD}

Vocational technical schools (hereinafter referred to as vocational schools) this is to cultivate the pragmatic competence and capabilities for technology research and development energy for the purpose of contingent due to the increase in the number of vocational high schools and universities in Taiwan in recent years, a significant dilution of limited educational resources, and seriously affect the high vocational schools update and replacement of equipment in the course of practice and internships; be imbalance in the allocation of resources for higher education, to make of vocational schools Spectrography equipment to enhance not only facing stagnation, and seriously out of line with the industry, the loss of the characteristics of the technical and vocational education, Therefore, public vocational high school teachers, equipment and curriculum enhancement, is necessary. Second, Taiwan is facing the industry recycling and global competition, in order to accelerate the quality of talent development and enhance the implementation depends on the re-enhancement of the vocational high school teachers, equipment and curriculum to strengthen technical and vocational education physique, cultivate pragmatic Zhiyong and good quality technical personnel [1].For the construction of Taiwan's economic blueprint, with the development of dynamic economies, to achieve sustainable 


\section{INTERNATIONAL JOURNAL Of RESEARCH -GRANTHAALAYAH

development concept, to promote love for Taiwan, Ma Xiao twelve building political, development wisdom Taiwan, strengthened industrial personnel training, in addition to technical and vocational university-industry resources, in order to activate education, make good use of vocational high schools in the research and development of energy, and promote the upgrading of industrial technology to solve the problem [2] [3]. Based on this concept in industrial recycling and activation of the technical and vocational, as shown in Figure 1, to improve the teaching quality of higher vocational school teachers enrich improve school teaching equipment, nurturing the the specialty forward-looking industry and pragmatic Zhiyong required personnel imperative for vocational high schools in Taiwan.

According to the National Taiwan University to study at first that at the outset that "the University academic, nurture talent and enhance the cultural, social services, for the purpose of promoting national development"; university tradition and chief responsibility of teaching, research and service functions personnel training, including the generation of knowledge (knowledge product), the innovation of knowledge (knowledge innovation) and knowledge sharing (knowledge share) [4]; Qiong Yang [5] also pointed out that university education (transfer of knowledge), scientific research (to create knowledge) and social services (knowledge) three functions. Thus, Kirby Yang [6] that the University is exploring the truth, undertaking research, transfer of knowledge, to nurture talents as well as the halls of the serving cell, Taiwan University education to be able to go beyond the challenges and the pursuit of excellence, the face of a knowledge-based economy triggered "industry knowledge" with the impact of the "knowledge industry" and "Technology Commercialization" trend [7], the university in addition to transfer its functions with the needs of the community for the effective operation of a school should strengthen industry-university cooperation further pursuit of diverse excellence.

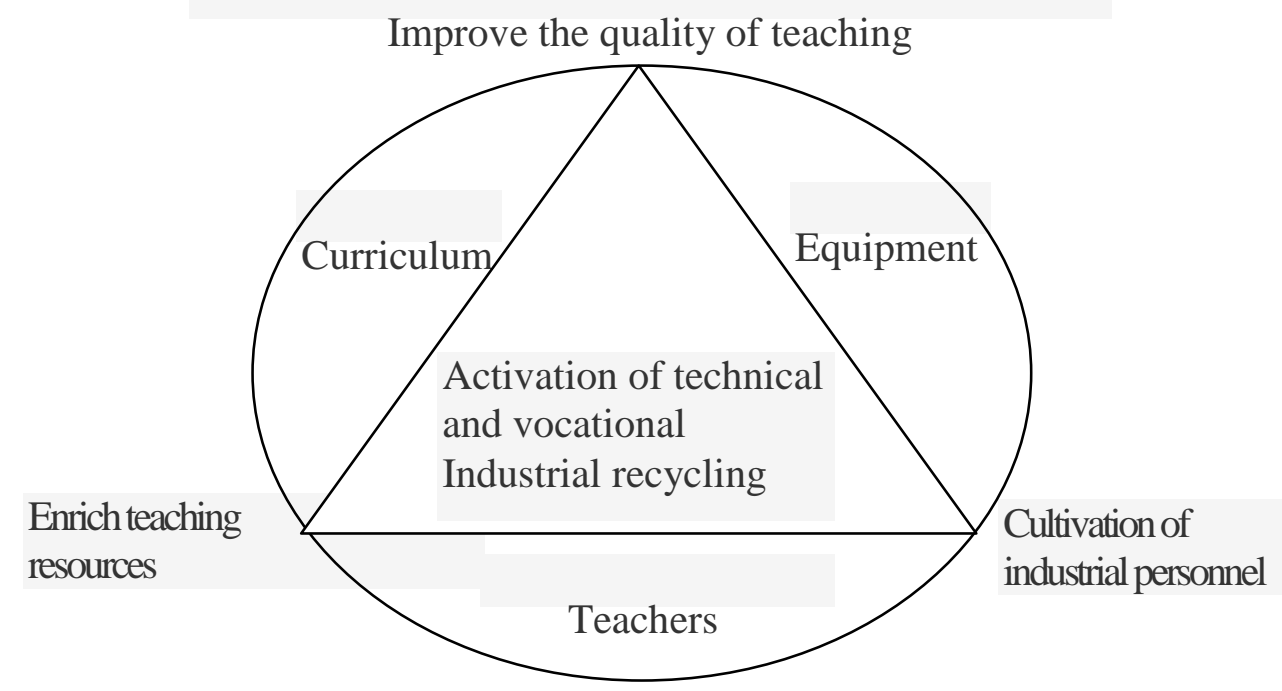

Figure 1. activation technical and vocational industrial recycling concept 


\section{INTERNATIONAL JOURNAL Of RESEARCH -GRANTHAALAYAH \\ A knowledge Repository}

Science

Reconstructed according to Taiwan CEPD 2015 Economic Development Vision three sprint Plan described in the vocational school system, described the current situation of the vocational education system in Taiwan, pointed out that the vocational school is facing four major problems need restructuring improvements to response to the needs of industry needs and student employment after graduation, the main problem (1) curriculum planning can not meet the industry demand; (2) certification system can not be combined with the needs of industry; (3) teachers promotion to the technical report by the ratio is still low, and (4) Vocational school's featureless [8]. Therefore, from Taiwan's Ministry of Education to promote technical and vocational education and recycling programs, positioned as "strengthen the pragmatic the Zhiyong development" and "implement nurture technical personnel role under its Strategy 5:" the establishment of technological and vocational specialty areas of development, "the practice of , stressed that the basis of the existing conditions and advantages in each vocational school, combined with the resources of the regional industry, and to establish the technical and vocational characteristics of higher vocational schools [9].

According to the aforementioned problem assessment, by strengthen teacher practice, improve Figure analyzer equipment and the development of specialized courses and other measures, in order to strengthen the vocational school constitution, enhance the economic vitality of Taiwan, to promote local industry and recycling, to the construction of Taiwan's new economic blueprint, based on the study The aimed personnel training plan to improve the characteristics of the Taiwan public vocational high school teachers, curriculum and Spectrography equipment. Therefore, the purpose of this study, combined with the development of the school both base and local industry resources, focus and specialty areas of planning the development of the public vocational colleges in Taiwan.

\section{THE RESEARCH FRAMEWORK}

According to the framework of this study, from to build new blueprint for Taiwan's economy, in order to improve the quality of vocational high schools in Taiwan reached the goal of recycling by the activation of Economy, Trade and Industry, the first to view the current situation, according to Taiwan's Ministry of Education, vocational school grant program analysis summarized in the direction of the field of development of vocational high schools, through the field of industry analysis and expert consultation, development of the spindle and the focus of investigations and public vocational schools, as research to enhance vocational school special industries cultivating talents planning reference focus.

And then based on various public vocational schools reported handling plan, compiled by various experts in the field and scholars public vocational schools in teachers, curriculum and equipment to handle the planned project, while after by the research team based on the foregoing information, the Department of whole in the field of handling projects and the necessary funding for the proposed budget, and developing follow-up to promote the Procedures and principles. 


\section{INTERNATIONAL JOURNAL Of RESEARCH -GRANTHAALAYAH \\ A knowledge Repository}

Science

Summarized the foregoing, as shown in Figure 2, can be reached to enhance the quality of public vocational school education recycling and activation of Economy, Trade and Industry, the current situation of the research grant program of public vocational schools, as well as the field of industry analysis and expert consultation areas defined; then by the the school development spindle and focus, for the sake of during the complete and thorough, total group meetings held eight times, work meetings, screenings explain and screenings expert consultation meeting to deliberation the field of personnel training for the project and requirements.

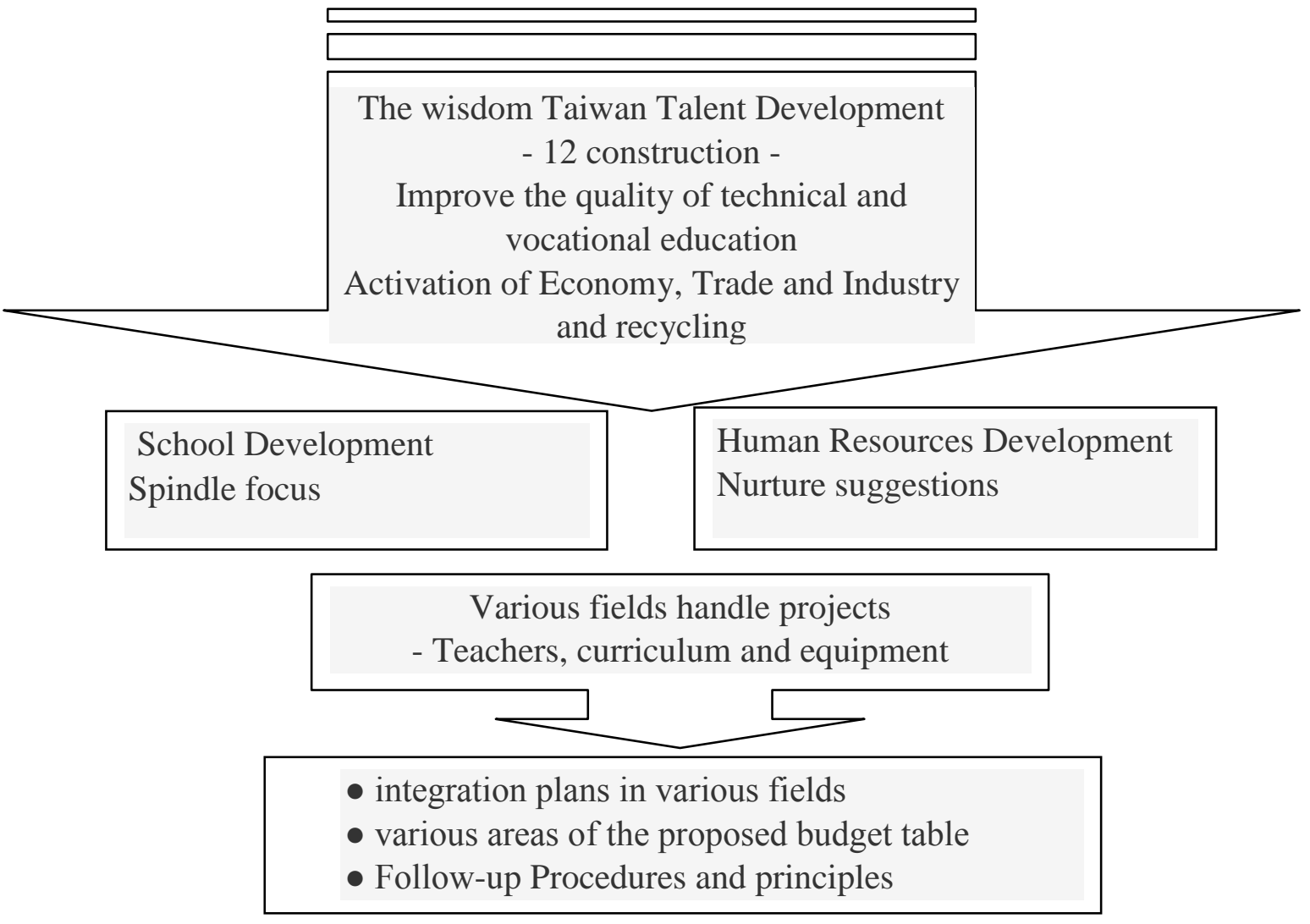

Figure 2. research chart

\section{ANALYSIS OF CURRENT SITUATION}

Current Taiwan Ministry of Education grant program, vocational school situation based on the framework of this study, the first to understand, then to recommend the focus areas of development, vocational schools, based respectively on the current grant program and school development field as follows:

a. the current grant program 


\section{INTERNATIONAL JOURNAL Of RESEARCH -GRANTHAALAYAH \\ A knowledge Repository}

Science

Technical and vocational education in Taiwan's main goal is to meet the need of economic construction, the quality and the amount of technical manpower; With the reform of the concepts and techniques of industrial production, the connotation and operation of vocational schools must meet the adjustment, in order to achieve the technical and vocational education goal to enhance Taiwan's economic competitiveness of the industrial development [10]. Taiwan's Ministry of Education authorities in addition to promote "the development of world-class universities and top research center plans" as well as awards University Teaching Excellence Plan, existing vocational high schools on the funding grant program, including the scope and content of a very wide, the main group of people are as follows:

(a) Ministry of Education awards colleges to set up regional teaching resource center plans to grant points.

(b) Ministry of Education handle Vocational School technology R \& D center applications and subsidy rules.

(c) Ministry of Education awards grants Private Vocational School whole development funding is allocated and application points.

(d) The important feature of the subsidy of the Ministry of Education personnel training in the field of the operating points of the improvement plan.

(e) Ministry of Education, vocational high schools in the development of the the school key features and integrated project plan to promote vocational school.

(f) Ministry of Education, Counseling Private Vocational Schools to improve teacher quality Implementation Guidelines.

(g) Ministry of Education grants vocational high schools to apply for international cooperation and exchange program application points.

(h) Ministry of Education to enhance vocational school students in general education and language ability to improve the plan.

(i) Ministry of Education grants to start industrial manpower rooted plan review guidelines are.

These various schemes and grants focus on nothing but strengthen schools, teachers, students and the industry, the content covers teachers, teaching resources, technology research and development, focusing on specialty, international exchanges, general education and language application ability, etc., then no each horizontal integration and vertical integration of the program, sometimes overlapping or slightly heterogeneous, not highlight the focus and characteristics of the development of vocational high schools, is not easy to focus in schools to promote and perform the necessary talent and promoting technological upgrading for the cultivation of industrial as should be integration and system thinking, square enough to promote the upgrading of industrial technology and cultivate the practice talent, based on how the integration of the current various subsidy schemes of vocational high schools, technical and vocational planning focus of future development and characteristics of the field, in order to activate education, promoting the industry of recycling, enhance the economic vitality of the concept of sustainable Taiwan. 


\section{INTERNATIONAL JOURNAL Of RESEARCH -GRANTHAALAYAH \\ A knowledge Repository}

Science

First of all, according to the Ministry of Education Awards colleges set up regional teaching resource center program grants points for precision machinery, power electronics, optical and electrical and communications, the biotech medical and agricultural and fishery, cultural and creative industries, digital content and environmental ecology and meal trip other services in six fields, as well as the center of the field school, co-organized school and partner schools compiled, are shown in Table 1 for the Taiwan Ministry of Education to strengthen vocational school technology R \& D center talent nurturing six areas, including precision machinery, power electronics the field of optical and electrical machinery and communications, the biotech medical and agricultural and fishery, the cultural and creative industries and digital services, environment, ecology and hospitality services.

Table 1. the Ministry of Education to strengthen the vocational school technology $R$ \& $D$ center talent nurturing six areas

\begin{tabular}{|c|l|c|l|}
\hline NO & \multicolumn{1}{|c|}{ Sequence Fields } & NO & \multicolumn{1}{|c|}{ Sequence Fields } \\
\hline 1 & Precision Machinery & 4 & $\begin{array}{l}\text { The biotech medical and agricultural and } \\
\text { fishery }\end{array}$ \\
\hline 2 & Power Electronics & 5 & $\begin{array}{l}\text { Cultural and creative industries and digital } \\
\text { services }\end{array}$ \\
\hline 3 & $\begin{array}{l}\text { Of light electromechanical and } \\
\text { communication }\end{array}$ & 6 & $\begin{array}{l}\text { Environment and ecology and Hospitality } \\
\text { Services }\end{array}$ \\
\hline
\end{tabular}

Another basis for the "handle Vocational School for the Ministry of Education Development School Key Features and promote vocational school integration project plan", as shown in Table 2, from 95 years (2006) to 97 (2008) annual subsidy public vocational schools focus on specialty plan subsidy amount, in addition to public Kinmen Institute of Technology, the Ministry of Education in Taiwan nearly three years the key characteristics grant program of public vocational schools a total of 99 times, the amount of subsidy of 540 yuan (Total $\$ 573,821,440$ ).

Table 2.95(2006) years to 97(2008) years to subsidize public vocational school subsidy amount

\begin{tabular}{|l|l|c|c|l|r|}
\hline NO & \multicolumn{1}{|c|}{ School } & $\begin{array}{l}\text { Subsidy } \\
\text { amount }\end{array}$ & NO & & School \\
\hline 01 & $\begin{array}{l}\text { National Taiwan University } \\
\text { of Science and Technology }\end{array}$ & $60,200,000$ & 11 & $\begin{array}{l}\text { Taipei College of } \\
\text { Business }\end{array}$ & $11,000,000$ \\
\hline 02 & $\begin{array}{l}\text { National Taipei University of } \\
\text { Technology }\end{array}$ & $43,530,000$ & 12 & $\begin{array}{l}\text { Taichung Institute of } \\
\text { Technology }\end{array}$ & $8,530,000$ \\
\hline 03 & $\begin{array}{l}\text { National Yunlin University of } \\
\text { Science and Technology }\end{array}$ & $37,470,440$ & 13 & $\begin{array}{l}\text { Pingtung Business } \\
\text { School }\end{array}$ & $9,840,000$ \\
\hline 04 & $\begin{array}{l}\text { Kaohsiung First University of } \\
\text { Science }\end{array}$ & $26,490,000$ & 14 & $\begin{array}{l}\text { Kinmen Institute of } \\
\text { Technology }\end{array}$ \\
\hline 05 & $\begin{array}{l}\text { Kaohsiung University of } \\
\text { Applied Science }\end{array}$ & $36,652,000$ & 15 & $\begin{array}{l}\text { Kaohsiung Hospitality } \\
\text { College }\end{array}$ & $19,750,000$ \\
\hline
\end{tabular}




\section{INTERNATIONAL JOURNAL Of RESEARCH -GRANTHAALAYAH \\ A knowledge Repository}

Science

\begin{tabular}{|l|l|l|l|l|r|}
\hline NO & \multicolumn{1}{|c|}{ School } & $\begin{array}{c}\text { Subsidy } \\
\text { amount }\end{array}$ & NO & School & Subsidy amount \\
\hline 06 & Formosa University & $46,560,000$ & 16 & Taiwan Junior College & $10,648,000$ \\
\hline 07 & Yi University of Technology & $22,490,000$ & 17 & $\begin{array}{l}\text { Taipei College of } \\
\text { Nursing }\end{array}$ & $43,246,000$ \\
\hline 08 & $\begin{array}{l}\text { National Pingtung University } \\
\text { of Science and Technology }\end{array}$ & $59,650,000$ & 18 & $\begin{array}{l}\text { Taichung } \\
\text { College }\end{array}$ & $14,900,000$ \\
\hline 09 & $\begin{array}{l}\text { Kaohsiung Marine HKUST } \\
\text { Karsing }\end{array}$ & $43,520,000$ & 19 & $\begin{array}{l}\text { Tainan College of } \\
\text { Nursing }\end{array}$ & $17,364,000$ \\
\hline 10 & $\begin{array}{l}\text { Penghu University of Science } \\
\text { and Technology }\end{array}$ & $45,781,000$ & 20 & $\begin{array}{l}\text { Taitung } \\
\text { College }\end{array}$ & $16,200,000$ \\
\hline \multicolumn{7}{|c|}{ Total amount of subsidy } \\
\hline
\end{tabular}

In addition, Taiwan's Ministry of Education required manpower gap to fill industrial development at this stage, effective support Taiwan technology industry R \& D and innovation, and enhance the competitiveness of Taiwan's technology industry, in particular to promote the University hospital settings industrial R \& D Master Program, the areas of the technology industry in Taiwan R \& D manpower supply Electrical (including electronics, electrical engineering, electronic control, telecommunications, and Information Engineering, optoelectronics, etc.), the main materials, physics and related cross-curricular areas. Shown in Table 3, for the expansion of the master's level industrial R \& D manpower supply program priorities Features 94 (2005) 98 (2009), annual public vocational school classes circumstances compiled table, the total of the approved enrollment of 1729, 94 Approved recruit 387, 95 (2006) Approved enrollment of 413, 96 (2007) Approved enroll 315, 97 (2008) 371 Approved enrolled, 98 (2009) (Spring semester only) for approval to recruit 243.

Table 3. expand the master's level industrial $R$ \& D human 94 (2005) -98 (2009) annual public vocational high school classes in the case

\begin{tabular}{|c|c|c|c|}
\hline \multirow{2}{*}{ By year } & \multicolumn{2}{|c|}{ Authorized strength Total number of } & \multirow{2}{*}{ Total number of } \\
\cline { 2 - 3 } & Spring Semester & Fall Semester & 387 \\
\hline 94 year(2005) & 74 & 313 & 413 \\
\hline 95 year(2006) & 244 & 169 & 315 \\
\hline 96 year(2007) & 35 & 280 & 371 \\
\hline 97 year(2008) & 124 & 247 & 243 \\
\hline 98 year(2009) & 243 & -- & 1729 \\
\hline \multicolumn{2}{|c|}{ Total number of } \\
\hline
\end{tabular}




\section{INTERNATIONAL JOURNAL Of RESEARCH -GRANTHAALAYAH \\ A knowledge Repository}

Science

In addition, according to Taiwan's Ministry of Education grants start industrial manpower rooted plans to review the Operational Guidelines, 97 (2008), the year a total of 57 schools and 98 plan grants citizens do vocational high schools, grant funding totaling $\$ 97,858,000$, of which total public vocational schools 8 schools and 35 plans received subsidies of $\$ 23,109,000$, as shown in Table 4, the number of industrial manpower for the Ministry of Education, 97 (2008) annual subsidy grounded in various public and private vocational high schools, compiled chart of the number of plans and grant funding object grants in the program for the citizens to do the large colleges mold, surface treatment, precision machinery and textile related departments, in Table 4, Taiwan's Ministry of Education, 97 (2008) annual subsidy industry manpower rooted school plan table compiled and grant funding.

Table 4. the Ministry of Education, 97 (2008) annual subvention industry human take root in schools, the number of plans and grant funding

\begin{tabular}{|l|c|c|c|}
\hline \multicolumn{1}{|c|}{ Object } & Number of schools & The number of plans & Grant funding \\
\hline $\begin{array}{l}\text { Private Vocational } \\
\text { School }\end{array}$ & 57 & 98 & $97,858,000$ \\
\hline $\begin{array}{l}\text { Public vocational } \\
\text { schools }\end{array}$ & 8 & 35 & $23,109,000$ \\
\hline
\end{tabular}

b. school development field

According to Taiwan's Ministry of Education, the current subsidy Vocational school plan: 1. Ministry of Education to strengthen personnel training program of technology research and development center of vocational schools; 2. Ministry of Education grants start industrial manpower rooted plans to review the operating points and $3 \mathrm{MOE}$ important characteristics leading domain talent cultivate improvement plan, and 4 top university teaching excellence each school to develop the field or characteristics, in order to analyze the other areas of the school to develop, CD Teaching Excellence program is based mainly on teaching, the field of development of the schools do not easy alignment analysis, such as public Taipei Technology University's teaching excellence promoted by all lines for the whole school, unable to carry out the field of other classified. 12 summarized the field of development of public vocational schools recommended precision machinery, coupled with the key service, a total of precision machinery, power electronics, optical, mechanical and electronic communications industry, the biotech medical, agricultural industries, the cultural and creative digital content environment and ecology, hospitality services, health care, marine industry and focus on service 13 industries.

c. field types and industry content

Learn more about the field continued to finishing the area of the proposed development and corresponding industry content types and industry content, will serve as the follow-up experts and scholars to consult the reference data. And for more in-depth description of the other connotation of the field and key projects, as well as human nurturing recommended (1) curriculum development proposals (2) development of teachers and equipment recommendations (3) employment development proposals have a clearer understanding of the field of preparation 


\section{INTERNATIONAL JOURNAL Of RESEARCH -GRANTHAALAYAH \\ A knowledge Repository}

Science

of development content types and corresponding industry recommended table - Reference and fill out the description, commissioned experts and scholars in various fields written in various fields do not nurture and corresponding industry and human recommendations. Where other description of the field of project content, in a narrative Instructions field connotation; the key project first sub categories under further subdivided Sector; the human nurturing proposed curriculum development recommendations to the workplace should have a basic professional competence Why? why should attend professional courses? addition to professional competence, workplace should have the basic ability of that? "to fill in the other information about teacher quality and device development proposals, how to" school to nurture the talents of its faculty and equipment improve? with industry standards? "to fill in, in addition to employment development proposals," the future direction of industrial development, why? required manpower quality why? manpower supply and demand situation for that? "to fill in the data obtained to collect oriented research in various fields nurture and the industrial contents, as well as humanrecommended reference.

In addition, the focus of future development and direction of public vocational schools deliberations, for future reference medium-range plans for teachers, equipment and curriculum development of Taiwan's Ministry of Education, the current public vocational schools to accept the Ministry of Education funding various grant projects, such as: "reward Teaching Excellence Plan, the important feature cultivating talents in the field of vocational schools, technical R \& D Center and the Human Resources Development Service rooted" plans subsidy case and Hengzhuo future industrial development and personnel needs, and the future may be expected to develop the vision and direction of the school, with the existing teaching staff, equipment and courses, planning the next four years, the focus of school development, industry needs and cultivating talents to promote and spindle.

\section{RESOURCE REQUIREMENTS}

Not according to the aforementioned areas and industry content, as well as the public vocational schools next school vision and direction, with the purpose of the research program, apply for the pilot program application instructions will 97 (2008), on November 17 brought together 20 public vocational school business director (Dean of Research and Development) and the head of the business contractor (director) Description schools reporting to the Ministry of Education grants public vocational schools to improve teacher and curriculum - pilot program application form for this compile research, develop in various fields to expert meetings to handle the needs of the projects and the proposed budget.

a. The pilot program application form

Public vocational school, apply for the pilot program application instructions will fill in "the Ministry of Education grants public vocational high schools to improve teacher and curriculum pre-plan application form, application form can be divided into three parts:

(a) Basic data: fill in nearly annual grant program with funding of the Ministry for Education. 


\section{INTERNATIONAL JOURNAL Of RESEARCH -GRANTHAALAYAH

(b) apply for the plan: mainly handle the project number, the name of the scheme and the annual work.

(c) each sub-plan plan: By handling plan breakdown purpose program content, funding needs, as well as the expected benefits.

Public vocational schools in accordance with current accepted the Ministry of Education funding for various grant projects, such as: the "reward Teaching Excellence Plan, the important feature of the field of personnel training", "Vocational school technology R \& D center and industrial manpower rooted" plan subsidy case and Hengzhuo the future industrial development and demand for talent, as well as the school may be expected to develop in the future vision and direction, with the existing teaching staff, equipment and courses, the school development plan for the next four years, the industry needs and cultivating talents to promote focus and spindle, reporting pre-plan application form.

b. The estimate of the financial needs

Plan Application Form 20 public vocational schools reported early, and then invited experts and scholars of various fields of 87 (40 of 47 scholars and industry), 97 (2008) of 13 December meeting of the north and south two times the funding schools improve teacher mentioning research equipment and curriculum sub-plan, re-summarized the plan handled in various fields, to develop recommendations to promote various projects in the field, as well as the purpose of the projects, the content and the expected benefits..

In addition, the pilot program reported aggregate public vocational school application form requirements, Table 5 for the budgetary requirements of advance planning to improve the vocational school teachers, equipment and curriculum table, respectively, in accordance with the quality of teachers, equipment and courses with different years are set out the estimated requirements, the proposed budget for enlisted by the table, enlisted a total of 4,878,564 thousand projects in teacher enlisted a total of 855,384 thousand enlisted a total of 2,900,255 thousand, respectively, in terms of equipment, provision of a total of 1,122,925 thousand in the curriculum in the first year; respect of the year in terms of provision 1,329,354 thousand, the provision of a total of 1,269,956 thousand in the second year, enlisted a total of 1,184,663 thousand in the 3rd annual provision of a total of 1,092,395 thousand in the 4th year.

Table 5. improve vocational school features industry talent nurturing funding Almost

\begin{tabular}{|c|c|c|c|c|c|}
\hline \multicolumn{1}{|c|}{ UO } & 1 year & 2nd Annual & 3rd Annual & 4th Annual & Total \\
\hline Teachers & 216,585 & 215,786 & 214,857 & 208,558 & 855,384 \\
\hline Equipment & 826,595 & 776,310 & 687,725 & 606,625 & $2,900,255$ \\
\hline Curriculum & 286,075 & 277,760 & 281,980 & 277,110 & $1,122,925$ \\
\hline Total & $1,329,354$ & $1,269,956$ & $1,184,663$ & $1,092,395$ & $4,878,564$ \\
\hline
\end{tabular}




\section{INTERNATIONAL JOURNAL Of RESEARCH -GRANTHAALAYAH \\ A knowledge Repository}

Science

\section{CONCLUSIONS AND RECOMMENDATIONS}

The study confined to research the process entirely sufficient, therefore, while the period in line with future major industrial development policies, and meet the needs of industrial development in the field, and would like to promote the process flow as well as handling the principle, reference is recommended that subsequent actual promotion.

\section{a. Procedures}

Planning based on this study, it is for the process of elaboration of follow-up, the hands start with the formulation of the plan implementation program correction start, integrated handle projects, the application, review, implementation, visits and effectiveness evaluation procedures, processes and instructions The detail shown in Figure 3. Mainly including the assessment phase, and plans to apply for the stage and is scheduled to run time.

\section{b. apply for principles}

In order to strengthen the development of vocational high schools in Taiwan, for the manpower needs of the industry, strengthen faculty research and development expertise, improve teaching methods and quality, update teaching and research facilities and equipment, to enrich teaching and resource materials, sophisticated, and the development of practical courses strengthen students before graduation The job readiness knowledge, I would like to put forward the principle of promoting the process for the follow-up to facilitate the preparation of the reference of the specific embodiments conclusion.

(a) Prospects for excellence: the combination of the key objectives of the economic construction, to provide the quality and the amount of technical manpower; introduction of the production concept and technological innovation of the production company's philosophy, and the development of vocational schools foresight excellent courses, and thus enhance the competitiveness of China's economic and industrial development.

(b) activating technical and vocational: strengthen teacher practice, improve Figure analyzer equipment and the development of specialized courses and other measures, the promotion of vocational high schools focus on the development and characteristics of the field, in order to activate the technical and vocational education, and promote the recycling of industrial and enhance the vitality of the economy, to achieve permanent continued development of technical and vocational education philosophy.

(c) Performance Responsibility: written basis for the application for the school plan selection by secondary schools, vocational high schools elected according to plan execution, and accept this Part, every year on a regular basis to assess the use of funds situation and implementing effective.

(d) installments promote: mining stage, strategically promote Optional determined year by year, and the phased implementation of public vocational schools and field projects, in order to 


\section{INTERNATIONAL JOURNAL Of RESEARCH -GRANTHAALAYAH \\ A knowledge Repository}

Science

achieve a comprehensive upgrade of the school curriculum, teaching and equipment, as well as to promote the objectives of industrial recycling .

\section{ACKNOWLEDGEMENTS}

This article is from the Ministry of Education, 98 academic year research program to improve vocational schools teachers, most of the research equipment and course advance planning work plans. "Adapted from, thanks to the Ministry of Education grant funding for research

\section{REFERENCES}

[1] JuhaVaso, K.T.The baldrige criteria for educational institutions. Milwaukee, Wisconsin: America Society for Quality. 2007

[2]Ministry of Education. The number of dropouts in colleges - classify according to the reason of dropout, gender, and grade. Feb 2, 2010. Source: http://www.edu.tw/files/site_content/b0013/98_s10b.xls

[3]Directorate-General of Budget, Accounting and Statistics,Executive Yuan. Human resource investigation statistic indices abstract. April 20, 2010. Source: http://www.dgbas.gov.tw/public/Attachment/03259495671.xls.

[4] Zhang, Ya-hui. High education depreciation! CEOs only gave a score of 48 on satisfaction. Chinatimes. April 22, $2010 . \quad$ Source: http://news.chinatimes.com/realtime/0,5255,110107x112010042201209,00.html.

[5]Ministry of Education. Net enrollment rate of college students. Feb 2, 2010. Source: http://www.edu.tw/files/site_content/B0013/106-23.xls. 2009.

[6]Ministry of Education. Teaching Excellence Award Project (Amended). Taipei City: Ministry of Education. 2008.

[7]Southern Taiwan University. Excellent achievement reports of Teaching Excellence Award Project of 2008. July, 2009.

[8]China medical University. The grants issuing of alert students in financial difficulties. August 30, 2010. Source:http://www.cmu.edu.tw/statute/statute_detail.php?sn=710. 